\title{
Kinetic and toxicological effects of synthesized palladium(II) complex on snake venom (Bungarus sindanus) acetylcholinesterase
}

\author{
Mushtaq Ahmed ${ }^{1 *}$ (D), Shahan Zeb Khan ${ }^{2}$, Naila Sher $^{1}$ (D), Zia Ur Rehman²*, Nadia Mushtaq ${ }^{3}$, Rahmat Ali Khan ${ }^{1}$ \\ 'Department of Biotechnology, University of Science and Technology Bannu-KPK, Pakistan. \\ ${ }^{2}$ Department of Chemistry, Quaid-i-Azam University, Islamabad, Pakistan. \\ ${ }^{3}$ Department of Botany, University of Science and Technology Bannu-KPK, Pakistan.
}

\section{Keywords:}

Palladium (II) complex

Snake venom

Acetylcholinesterase

Inhibition

Kinetics

\begin{abstract}
Background: The venom of the krait (Bungarus sindanus), an Elapidae snake, is highly toxic to humans and contains a great amount of acetylcholinesterase (AChE). The enzyme AChE provokes the hydrolysis of substrate acetylcholine (ACh) in the nervous system and terminates nerve impulse.

Different inhibitors inactivate $\mathrm{AChE}$ and lead to ACh accumulation and disrupted neurotransmission.

Methods: The present study was designed to evaluate the effect of palladium(II) complex as antivenom against krait venom AChE using kinetics methods.

Results: Statistical analysis showed that krait venom AChE inhibition decreases with the increase of $\mathrm{Pd}(\mathrm{II})$ complex $(0.025-0.05 \mu \mathrm{M})$ and exerted $61 \%$ inhibition against the $\mathrm{AChE}$ at a fixed concentration $(0.5 \mathrm{mM})$ of ACh. Kinetic analysis using the Lineweaver Burk plot showed that Pd(II) caused a competitive inhibition. The compound Pd(II) complex binds at the active site of the enzyme. It was observed that $K_{\mathrm{m}}$ (MichaelisMenten constant of AChE-ACh into AChE and product) increased from 0.108 to 0.310 $\mathrm{mM}$ (45.74 to $318.35 \%)$ and $V_{\max }$ remained constant with an increase of $\mathrm{Pd}(\mathrm{II})$ complex concentrations. In AChE $K_{\text {Iapp }}$ was found to increase from 0.0912 to $0.025 \mu \mathrm{M}$ (29.82-72.58\%) and did not affect the $V_{\text {maxapp }}$ with an increase of ACh from (0.05-1 $\mathrm{mM}) . K_{\mathrm{i}}$ (inhibitory constant) was estimated to be $0.029 \mu \mathrm{M}$ for snake venom; while the $K_{\mathrm{m}}$ was estimated to be $0.4 \mathrm{mM}$. The calculated $\mathrm{IC}_{50}$ for $\mathrm{Pd}(\mathrm{II})$ complex was found to be $0.043 \mu \mathrm{M}$ at constant ACh concentration $(0.5 \mathrm{mM})$.

Conclusions: The results show that the $\mathrm{Pd}(\mathrm{II})$ complex can be deliberated as an inhibitor of AChE.
\end{abstract}

\footnotetext{
* Correspondence: mushtaq213@yahoo.com and zrehman@qau.edu.pk https://doi.org/10.1590/1678-9199-JVATITD-2020-0047

Received: 07 April 2020; Accepted: 29 October 2020; Published online: 09 April 2021
} 


\section{Background}

Acetylcholinesterase (AChE) (EC.3.1.1.7) is a serine hydrolase that is found in peripheral and central tissues; sensory and motor fibers; cholinergic and non-cholinergic fibers; and in nerves and muscles. In motor neurons, AChE presents higher activity as compared to sensory neurons [1]. Its main biological role is the hydrolysis of ACh into acetate and choline to terminate impulse transmission. AChE has a remarkably high specific catalytic activity, especially for a serine hydrolase, each molecule of AChE degrades about 25000 molecules of ACh per second $[2,3]$. AChE consists of two sites i.e. the peripheral site (p-site) and the anionic binding site [4]. The anionic binding site has two further domains: the ionic site that consists of serine and histidine, and the esteratic site that contains glutamate $[4,5]$. The serine residue of the ionic site is responsible for substrate hydrolysis while histidine residue acts as base and acid during hydrolytic processes. In the esteratic site, the glutamate residue clutches the cationic head of the substrate ACh $[4,5]$. The acetylcholine (ACh) is a neurotransmitter that is found in many autonomically innervated organs, in the neuromuscular junction, in many synapses, in all autonomic ganglia, and in the central nervous system. The neurotransmitter ACh plays a major role in physiological events and is inactivated by AChE through enzymatic breakdown [6, 7]. ACh is degraded into choline and acetate by AChE [8]. Alzheimer's disease (AD) patients can be treated by degeneration of this pathway [9].

Neurodegenerative diseases induce changes in the central nervous system (CNS) [10]. As it is widely known, $\mathrm{AD}$ is a neurodegenerative disorder that causes dementia among elderly people [11, 12]. Acetylcholinesterase inhibitors (AChEI) can help in the treatment of numerous pathologies, including glaucoma, Lewy body dementia, myasthenia gravis, and AD [13]. AChE inhibition is known to treat $\mathrm{AD}$ by improving functions and the ACh amount in the cholinergic synapses.

Snake venom AChE is monomeric while in all mammals it is a multimeric form, with two or more subunits $[14,15]$. Snakes of the Elapidae family have a large number of ACHE enzymes [16] and are found in several parts of the world [17]. Bungarus sindus venom contains about 747,000 Ellman's units per $g$ of dry venom of AChE-like activity, and is one of the richest venoms with such activity [16]. Therefore, for analyzing AChE mechanism, Bungarus sindus venom is an excellent model [18].

According to the World Health Organization, 5.4 million snake bites are reported each year globally. Out of the 2.5 million people affected, about 125,000 of them die. In rural areas, death from snakebite is a significant public health problem and people of these areas have no access to antivenom [19]. There are approximately 10,000 to 50,000 snakebite-related deaths in India every year [20]. In Asia, most of the deaths attributable to snakebite involve members of the family Elapidae [20,21]. To treat snakebite victims, antivenom is the most specific therapy [22]. Some bio-organometallic showed how rational ligand can be designed for new improved therapies [23].
Heteroleptic Pd(II) complex compounds were the first molecules that were discovered for therapeutic purposes [24]. Recently, the literature has shown that these compounds possess neuroprotective effects, and thus increase the scientific interest in the pharmaceutical industry $[25,26]$. A variety of compounds from different origins were discovered and reported to be effective against several diseases, including the neurological ones, such as $\mathrm{AD}[27,28]$. In vivo and in vitro studies have proven the medicinal value of these compounds [29].

The heterocyclic organic compounds bearing coumarin possess an important biological role in medicinal chemistry [30]. They are commonly used as cosmetics, food additives, perfumes, pharmaceuticals, laser dyes, and optical brighteners $[31,32]$. Recent studies have shown that Pd(II) complexes are about 105 times more combative as compared to Pt (II) analogs; the lower anti-AChE activity of Pd compounds has been ascribed to hydrolysis of the leaving groups that separate readily in solution, and leading to reactive species far from their pharmacological targets [33]. Due to the substantial similarity in the coordination chemistry of palladium [Pd(II)] and platinum $[\mathrm{Pt}(\mathrm{II})]$ the development of $\mathrm{Pd}(\mathrm{II})$-based drugs has received much importance after the cisplatin success in the cancer therapy [34]. The carbonyl group in $\mathrm{Pd}$ (II) complex acts as antiglycation,. Almost all Pd(II) complexes showed antiglycation potential and provoked suppression of disorders [34]. From the pharmacological point, $\mathrm{Pd}(\mathrm{II})$ complexes may be considered better inhibitors than those free of $\mathrm{Pd}(\mathrm{II})$, which are based on the potential ability of ligands to reduce the toxicity of free metal ion [34]. Pd(II) complex compounds are a class of irreversible AChE enzyme inhibitors that form a covalent bond between the esteratic site and phosphoryl group of the enzyme [35]. Phosphorus compounds irreversible bind to AChE by forming a covalent bond between the phosphoryl group and the esteratic site of the enzyme [36]. The present study aimed to investigate the antivenom potential of $\mathrm{Pd}(\mathrm{II})$ complex compound on krait (Bungarus sindanus) venom acetylcholinesterase (AChE) by in vitro methods.

\section{Methods Materials}

AChE, butyrylthiocholine iodide, DTNB [5,5'-dithiobis(2nitro-benzoic acid)], sodium dihydrogen phosphate, disodium hydrogen phosphate bovine serum albumin, Tris (hydroxymethyl aminomethane) and Coomassie Brilliant blue R-250 were purchased from Sigma (USA). All other reagents used were of analytical grade.

\section{Synthesis of palladium(II) complex}

The $\mathrm{Pd}(\mathrm{II})$ complex was synthesized as previously reported [37]. A stoichiometric amount of palladium(II) chloride reacted with diphenyl-p-tolyl phosphine and 4-diphenylmethylpiperazine1-carbodithioate using methanol and acetone as solvents. The synthesized Pd(II) compound was confirmed by using various 
technique i.e. CHNS, FT-IR and multinuclear NMR analysis as reported in our previous paper [37].

\section{Preparation of stock solution}

To prepare stock solution $2.5 \mathrm{mM}$ Pd(II) complex was dissolved in $2 \mathrm{~mL}$ DMSO which was further diluted to several solutions of different concentrations $0.025,0.037$, and $0.05(\mu \mathrm{M})$.

\section{Venom}

Male and female mature live snakes (Bungarus sindanus) were obtained from Thatta District of Sindh Province, Pakistan. A small amount of snake venom was milked manually, mixed, immediately lyophilized, powdered and then mixed with $1 \mathrm{~mL}$ $\mathrm{dH}_{2} \mathrm{O}$ and kept at $-20^{\circ} \mathrm{C}$ for future activities. The study was approved by the Departmental Ethical Approval Committee.

\section{Protein determination}

Bovine serum albumin was used as standard. The protein was assayed by following the procedure of Bradford [38]. About 2 $\mu \mathrm{g}$ protein was used for the enzymatic assay.

\section{Acetylcholinesterase assay}

In the present study, the anti-AChE activities of the Pd(II) complex were confirmed by the standard methodology of Ahmed [39], which was modified by Rocha [40]. AChE hydrolysis rates (V) were estimated at different substrate ACh concentrations (0.05-1 $\mathrm{mM}$ ) in $1 \mathrm{~mL}$ assay mixture with $10 \mathrm{mM}$ DTNB [5,5'-dithiobis(2-nitrobenzoic acid)] and $50 \mathrm{mM}$ phosphate buffer, $\mathrm{pH} 7.4$ at $25^{\circ} \mathrm{C}$. About $20 \mu \mathrm{L}$ of diluted Bungarus sindanus venom was also added to the above mentioned reaction mixture.

The mixtures were then incubated at $37^{\circ} \mathrm{C}$ for 5 minutes. After the addition of the substrate (ACh), the enzyme-substrate (AChE-ACh) reaction started immediately. The AChE-ACh hydrolysis rate was analyzed by the formation of thiolate dianion of DTNB after every 15 seconds during 90 seconds using a double beam spectrophotometer UV-1602, BMS biotechnology medical service. The measurement of the amount of the yellow color which develops from the AChE-ACh reaction revealed the AChE activity. All samples were run in triplicate.

\section{Kinetic determination}

The $\mathrm{Pd}(\mathrm{II})$ complex-AChE interaction rate was determined by using the Lineweaver [41] double reciprocal plot, by plotting $1 /$ rate of enzyme activity $(1 / \mathrm{V})$ against $1 /$ substrate $(1 / \mathrm{S})$ analyzed over a range of different substrate ACh concentrations (0.05-1 $\mathrm{mM})$ in the absence and presence of $\mathrm{Pd}(\mathrm{II})$ complex $(0.025,0.037$ and $0.05 \mu \mathrm{M})$. Michaelis Menten constant $\left(K_{\mathrm{m}}\right)$ was determined by two different plot of $1 / \mathrm{V}$ versus $1 / \mathrm{S}$ [41] and V versus V/S [42, 43]. The values of inhibition constant $\left(K_{\mathrm{i}}\right)$ were determined by using Cornish-Bowden plots of S/V versus [I]. $\mathrm{IC}_{50}$ was estimated at fixed $\mathrm{ACh}$ concentration $(0.5 \mathrm{mM})$, by following Dixon [44] plot using $1 / \mathrm{V}$ versus [I].

\section{Statistical analysis}

Statistical analysis was performed using one-way ANOVA, which was followed by post-hoc analysis (Duncan multiple range tests). The difference was considered to be significant for $\mathrm{p}<0.05$.

\section{Results}

\section{Pd(II) complex anti-acetylcholinesterase activity}

In the present study Pd(II) complex (Figure 1) inhibited snake venom AChE. We observed that at a fixed concentration 0.5 $\mathrm{mM}$ of substrate, Pd(II) complex showed $61 \%$ inhibition of AChE activity (Figure 2).

\section{Determination of $\mathbf{I} \mathbf{C}_{\mathbf{5 0}}$}

In the present study, at a fixed concentration of $0.5 \mathrm{mM}$ of the substrate (Figure 3), Pd(II) complex showed 50\% inhibition. IC calculated by plotting the percentage of residual activity versus inhibitor concentration. The $\mathrm{IC}_{50}$ value for $\mathrm{Pd}(\mathrm{II})$ complex was found to be $0.043 \mu \mathrm{M}$ (Table 1 ).

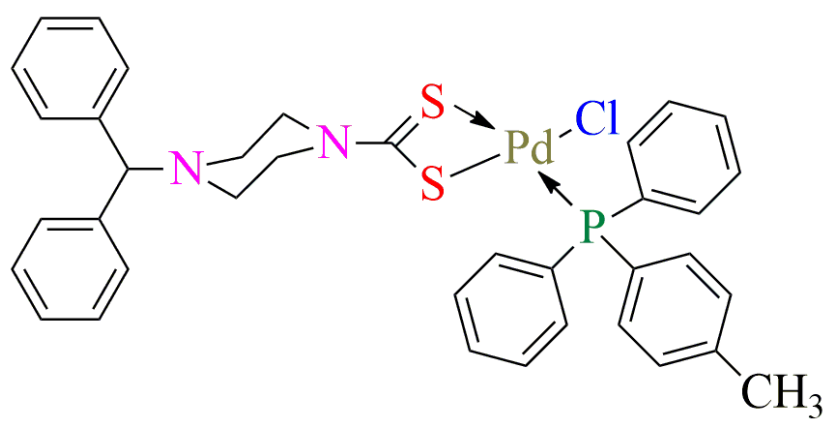

Figure 1. Chemical structure of $\mathrm{Pd}(I I)$ complex.

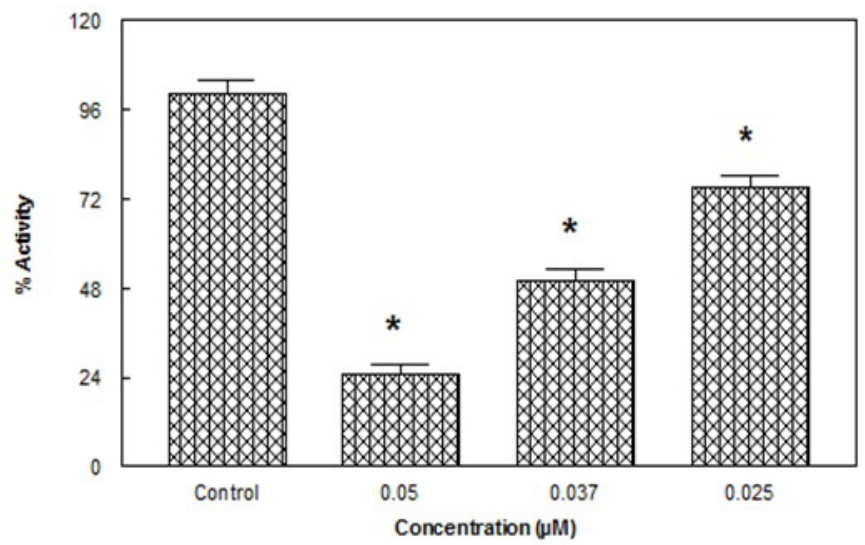

Figure 2. Concentration-dependent inhibition of krait snake venom AChE in the absence and presence of $\operatorname{Pd}(\mathrm{II})$ complex were measured at $412 \mathrm{~nm}$ by using $0.5 \mathrm{mM}$ substrate in $1 \mathrm{~mL}$ assay solution with $50 \mathrm{mM}$ phosphate buffer ( $\mathrm{pH}$ 7.4). $10 \mathrm{mM}$ DTNB [5,5-dithiobis(2-nitronenzoic acid)] was pre incubated for $10 \mathrm{~min}$ before $0.5 \mathrm{mM}$ substrate addition. All experiments were repeated at least two times and similar results were obtained. ${ }^{*} p<0.05$, significantly different from control. 
Table 1. Comparative study of kinetic parameters of cholinesterase inhibition by $\mathrm{Pd}(\mathrm{II})$ complex. $V_{\max }$ and $V_{\text {max }} / K_{\mathrm{m}}$ and of snake venom $\mathrm{AChE}$ at fixed $0.5 \mathrm{mM}$ substrate (ASCh).

\begin{tabular}{cc}
\hline Parameters & Snake venom AChE \\
\hline$K_{\mathrm{i}}(\mu \mathrm{M})$ & 0.029 \\
\hline$I C_{50}(\mu \mathrm{M})$ & 0.043 \\
\hline$K_{\mathrm{m}}(\mathrm{mM})$ & 0.4 \\
\hline$V_{\max }$ & 16.6 \\
\hline$V_{\max } / K_{m}$ & 41.5 \\
\hline
\end{tabular}

$K_{i}$ inhibition constant; $\mathrm{IC}_{50}$; half of maximal inhibitory concentration; $K_{\mathrm{m}}$ : Michaelis-Menten constant.

\section{Determination of $\boldsymbol{K}_{\boldsymbol{m}}$}

In the present study, $K_{\mathrm{m}}$ (Michaelis-Menten constant) was deliberate by using the Lineweaver-Burk plot and was estimated to be $0.4 \mathrm{mM}$ (Figure 4).

\section{Effects of Pd(II) complex on $K_{m}$ and $V_{\max }$}

Kinetics analysis revealed that $\mathrm{Pd}(\mathrm{II})$ caused competitive type inhibition against AChE (Figure 4). The $K_{\mathrm{m}}$ increased from 0.108 to $0.310 \mathrm{mM}$ (45.74 to $318.35 \%$ ) and the $V_{\max }$ was unchanged (Table 2).

\section{Effects of palladium(II) complex on $\boldsymbol{K}_{\text {lapp }}$ and $\boldsymbol{V}_{\text {maxapp }}$}

In the present study, $K_{\text {Iapp }}$ and $V_{\text {maxapp }}$ were observed for AChE (Figure 5). $K_{\text {Iapp }}$ was found to increase from 0.0912 to $0.025 \mu \mathrm{M}$ $(29.82-72.58 \%)$ and did not affect the $V_{\text {maxapp }}$ with an increase of the substrate ACh concentration (Table 3).

\section{Determination of inhibitory constants $\left(K_{i}\right)$}

$K_{\mathrm{i}}$ (inhibitory constant) was found to be $0.029 \mu \mathrm{M}$ (Figure 6). The values are presented in Table 1.

\section{Discussion}

Acetylcholinesterase (AChE) is a family of enzymes that catalyzes the hydrolysis of the neurotransmitter acetylcholine (ACh) into choline and acetic acid, a reaction necessary to allow a cholinergic neuron to return to its resting state after activation. AChE is a serine hydrolase mainly found at neuromuscular junctions and cholinergic brain synapses. Its principal biological role is termination of impulse transmission at cholinergic synapses by rapid hydrolysis of the neurotransmitter ACh to acetate and choline.

In the present study Pd(II) complex (Figure 1) inhibited cholinesterase in Bungarus sindanus venom. We observed that at fixed concentration $0.5 \mathrm{mM}$ of substrate $\mathrm{Pd}(\mathrm{II})$ complex showed

Table 2. Effect of Pd(II) complex on $K_{m}$ and $V_{\max }$ of Bungarus sindanus (krait) venom AChE.

\begin{tabular}{|c|c|c|c|}
\hline Pd (II) complex ( $\mu \mathrm{M} / \mathrm{mL})$ & $K_{m}(m M)$ & \% Increase & $\begin{array}{c}V_{\max }(\mu \mathrm{mol} / \mathrm{min} \text { per } \mathrm{mg} \\
\text { protein) }\end{array}$ \\
\hline 0 & 0.0741 & 0 & 20 \\
\hline 0.025 & 0.108 & 46 & 20 \\
\hline 0.037 & 0.230 & 211 & 20 \\
\hline 0.05 & 0.310 & 320 & 20.4 \\
\hline
\end{tabular}

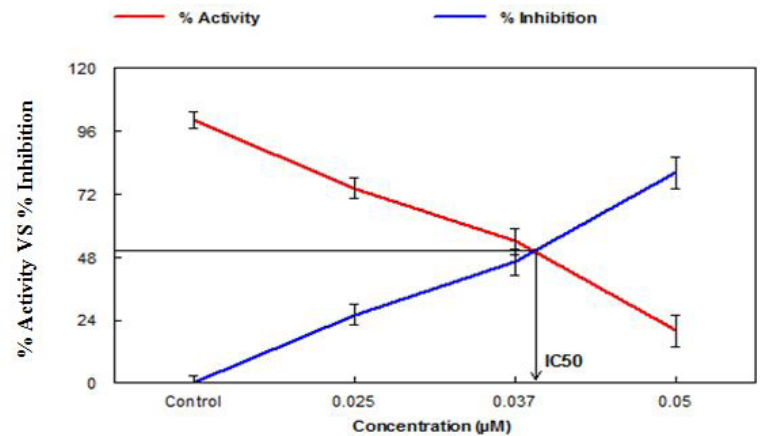

Figure 3. A plot of the percentage residual activity in the absence and presence of $\mathrm{Pd}(\mathrm{II})$ complex after 10 minute incubation at $37^{\circ} \mathrm{C}$ versus various concentration of $\mathrm{Pd}(\mathrm{II})$ complex. $0.5 \mathrm{mM} \mathrm{AcSCh}$ was used as a substrate for snake venom AChE. The results represent the mean of three different experiments done in triplicate.

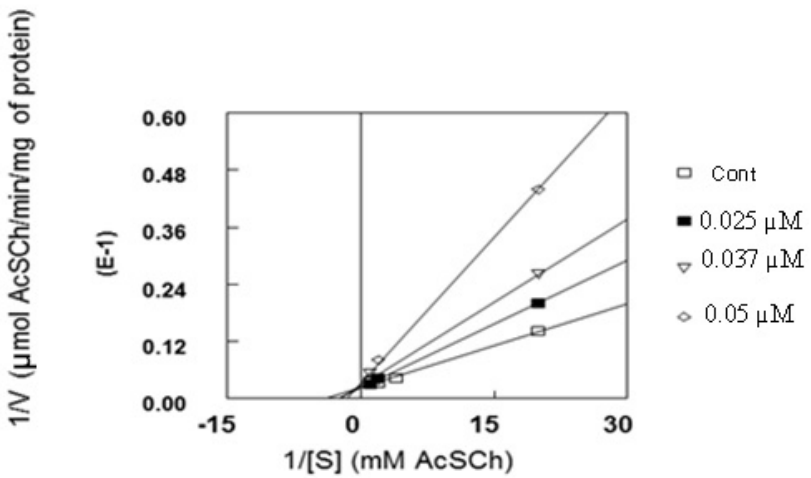

Figure 4. $\operatorname{Pd}(\mathrm{II})$ complex caused a competitive type of inhibition of krait snake venom AChE. Data are expressed in the form of Lineweaver-Burk (reciprocal of enzyme velocity versus reciprocal of $\mathrm{AcSCh}$ ) plot. The results represent the mean of three different experiments done in triplicate by using different concentration of $\mathrm{Pd}(\mathrm{II})$ complex. 
Table 3. Effect of Pd(II) complex on $K_{\text {lapp }}$ and $V_{\text {maxapp }}$ of Bungarus sindanus (krait) venom AChE. The $V_{\text {maxapp }}$ and $K_{\text {lapp }}$ were determined from Dixon plot of Figure 4 for snake venom acetylcholinesterase. The $V_{\operatorname{maxap}}$ is equal to the reciprocal of $y$-axis intersection of each line for each AcSCh/BuSCh concentration while $K_{\text {app }}$ is equal to the $x$-axis intersection in Dixon plot.

\begin{tabular}{cccc}
\hline $\begin{array}{c}\text { [ASCh] } \\
(\mathbf{m M})\end{array}$ & $\begin{array}{c}\boldsymbol{K}_{\text {lapp }} \\
(\boldsymbol{\mu} \mathbf{M} / \mathbf{m L})\end{array}$ & \% Increase & $\begin{array}{c}\boldsymbol{V}_{\text {maxapp }} \\
(\boldsymbol{\mu m o l} / \mathbf{m i n} \text { per } \boldsymbol{\mu M})\end{array}$ \\
\hline 0.05 & 0.0912 & 0 & 32.2 \\
\hline 0.1 & 0.064 & 30 & 32.2 \\
\hline 0.25 & 0.0426 & 54 & 32.2 \\
\hline 0.5 & 0.0292 & 68 & 31.25 \\
\hline 1.0 & 0.025 & 73 & 30.3 \\
\hline
\end{tabular}

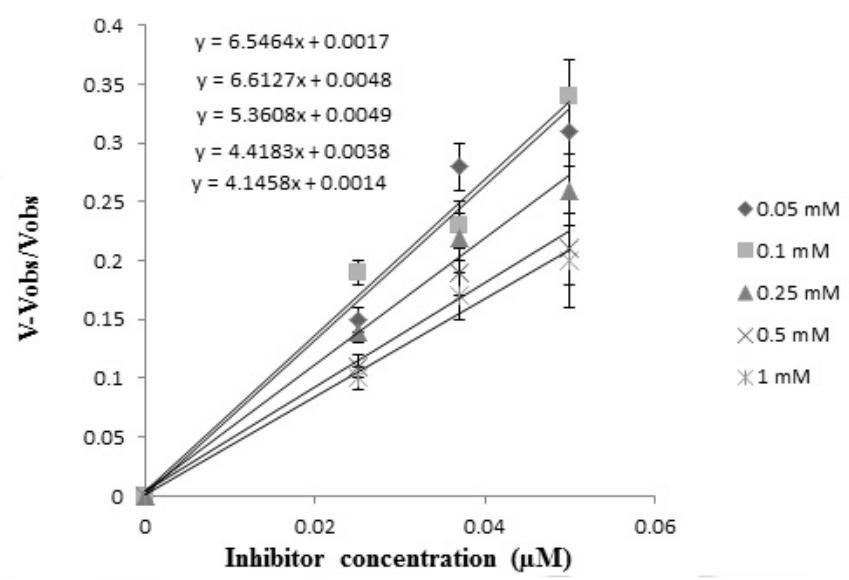

Figure 5. Effects of $\mathrm{Pd}(\mathrm{II})$ complex on $K_{\text {lapp }}$ and $V_{\text {maxapp }} K_{\text {lapp }}$ was found to increase from 0.0912 to $0.025 \mu \mathrm{M}(29.82-72.58 \%)$ while $V_{\text {maxapp }}$ remained unchanged with increase of substrate concentration $(0.05-1 \mathrm{mM})$.

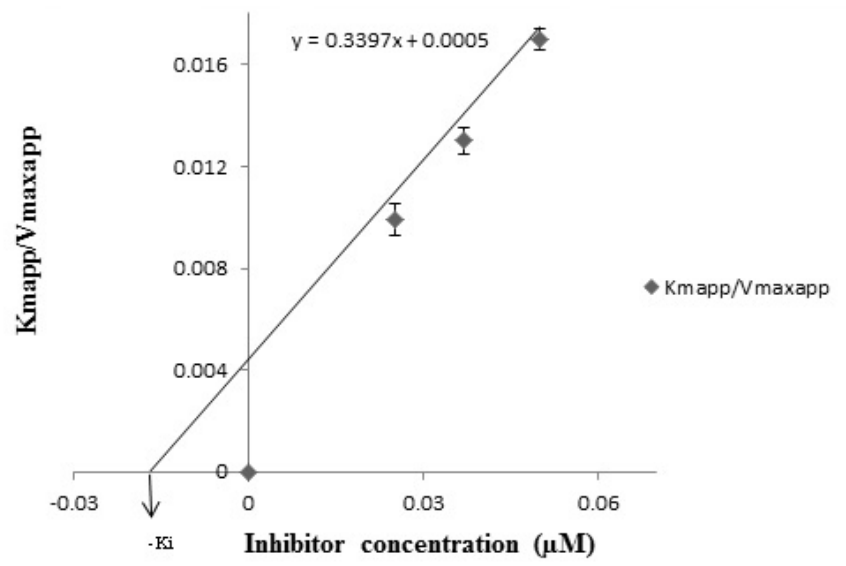

Figure 6. Determination of inhibitory constant $(K i)$.

$61 \%$ inhibition of acetylcholinesterase activity, (Figure 2). Also at a fixed concentration $0.5 \mathrm{mM}$ of substrate (Figure 3) $\mathrm{Pd}$ (II) complex showed $50 \%$ inhibition at concentration of $0.043 \mu \mathrm{M} / \mathrm{mL}$ (Table 1). In the comparative study, the $\mathrm{Pd}(\mathrm{II})$ complex $\mathrm{IC}_{50}$ value is very close to $\mathrm{AChE}$ traditional inhibitors (tacrine, rivastigmine and galantamine) $[45,46]$.
In the present study competitive inhibition was observed with venom $\mathrm{AChE}$ for the kinetic analysis (Figure 4). In this case the $K_{\mathrm{m}}$ increased from 0.108 to $0.310 \mathrm{mM}$ (45.74 to $318.35 \%$ ) and the $V_{\max }$ was unchanged (Table 2). This behavior was indicated by the line weaver Burk double reciprocal plot [47]. Pd(II) complex inhibited AChE in Bungarus sindanus (krait) venom using $\mathrm{ACh}$ as a substrate. In such type of inhibition, the inhibitor competes with the substrate for binding to the active site of the enzyme, and thus; adequate substrate molecules can move the inhibitor from the enzyme active site. The results of the Lineweaver-Burk analysis indicate that Pd(II) complex inhibited snake venom AChE in a dose-dependent mode [47]. The Pd(II) complex compete with substrate ACh for binding at the active site of the enzyme and it does not react with the active site but its function is to occupy or prevent the binding of any other molecule of the substrate. $K_{\mathrm{m}}$ (Michaelis-Menten constant of AChE-ACh into AChE and product) and $K_{\mathrm{i}}$ (inhibitory constant) were estimated from (Figure 4 and 6 ) and were found to be 0.4 $\mathrm{mM}$ and $0.029 \mu \mathrm{M}$ (Table 1 ). The $K_{\text {Iapp }}$ and $V_{\text {maxapp }}$ were observed for AChE (Figure 5) i.e. $K_{\text {Iapp }}$ was found to increase from 0.0912 to $0.025 \mu \mathrm{M}(29.82-72.58 \%)$ and did not affect the $V_{\text {maxapp }}$ with increase of the substrate ACh concentration (Table 3).

In the present study, it is shown that $\mathrm{Pd}$ (II) complex act in a scorpion-like fashion by binding with the peripheral site (p-site) and blocking the entry of substrate ACh toward the active site of the AChE enzyme [48]. These results are also supported by the study of Harel [49] which confirmed that the crystal structure of antidepressant tacrine [an inhibitor of AChE enzyme with a structure similar to that of Pd(II) complex].

\section{Conclusion}

Based on the kinetic parameter of AChE inhibition, we presume that due to the structural resemblance and ionic properties, Pd(II) complex compete with substrate ACh to bind with the active site of the enzyme. Furthermore, the results show that $\mathrm{Pd}$ (II) complex can be considered as an inhibitor of Krait snake venom AChE.

\section{Acknowledgments}

Not applicable.

\section{Availability of data and materials}

Data will be available as per requirement of Journal guide lines.

\section{Funding}

The present study was supported by the higher education commission of Pakistan via project n. 20-2171/NRPU/R\&D/ HEC/13/5610.

\section{Competing interests}

The authors declare that they have no competing interests. 


\section{Authors' contributions}

MA, SZK, ZUR and RAK conceived this research and designed experiments. NS, MA and NM performed experiments and analyzed data and wrote paper. All authors read and approved the final manuscript.

\section{Ethics approval}

The study was approved by the Departmental Ethical Approval Committee, ref. n. Biotech/Ethic/110.

\section{Consent for publication}

Not applicable.

\section{References}

1. Massoulie J, Pezzementi L, Bon S, Krejci E, Vallette FM. Molecular and cellular biology of cholinesterases. Prog Neurobiol. 1993 Jul;41(1):31-91.

2. Quinn DM. Acetylcholinesterase: enzyme structure, reaction dynamics, and virtual transition states. Chem Rev. 1987;87(5):955-79.

3. Taylor P, Radic Z. The cholinesterases: from genes to proteins. Annu Rev Pharmacol Toxicol. 1994;34:281-320.

4. Rosenberry TL, Johnson JL, Cusack B, Thomas JL, Emani S, Venkatasubban $\mathrm{KS}$. Interactions between the peripheral site and the acylation site in acetylcholinesterase. Chem Biol Interact. 2005 Dec 15;157-158(15):181-9.

5. Patrick GL. An introduction to medicinal chemistery. In: Cholinergics, anticholinergics and anticholiesterase; 2001.

6. Prody CA, Zevin-Sonkin D, Gnatt A, Goldberg O, Soreq H. Isolation and characterization of full-length cDNA clones coding for cholinesterase from fetal human tissues. Proc Nat Acad Sci U S A. 1987 Jun;84(11):3555-9.

7. Dave KR, Syal AR, Katyare SS. Tissue cholinesterases. A comparative study of their kinetic properties. Z Naturforsch C J Biosci. 2000 JanFeb;55(1-2):100-8.

8. Kelly RB, Deutsch JW, Carlson SS, Wagner JA. Biochemistry of neurotransmitter release. Annu Rev Neurosci. 1979;2:399-446.

9. Perry E, Walker M, Grace J, Perry R. Acetylcholine in mind: a neurotransmitter correlate of consciousness? Trends Neurosci. 1999 Jun;22(6):273-80.

10. Reitz C, Mayeux R. Alzheimer disease: epidemiology, diagnostic criteria, risk factors and biomarkers. Biochem Pharmacol. 2014 Apr 15;88(4):64051.

11. Kumar A, Singh A, Ekavali. A review on Alzheimer's disease pathophysiology and its management: an update. Pharmacol Rep. 2015 Apr;67(2):195-203.

12. Solomon A, Mangialasche F, Richard E, Andrieu S, Bennett DA, Breteler $M$, et al. Advances in the prevention of Alzheimer's disease and dementia. J Intern Med. 2014 Mar;275(3):229-50.

13. Nair VP, Hunter JM. Anticholinesterases and anticholinergic drugs. Contin Educ Anaesth Crit Care Pain. 2004 Oct 5;4(5):164-8.

14. Cousin X, Bon S, Duval N, Massoulie J, Bon C. Cloning and expression of acetylcholinesterase from Bungarus fasciatus venom. A new type of cooh-terminal domain; involvement of a positively charged residue in the peripheral site. J Biol Chem. 1996 Jun 21;271(25):15099-108.

15. Ahmed M, Latif N, Khan RA, Ahmad A, Rocha JBT, Mazzanti CM, et al. Enzymatic and biochemical characterization of Bungarus sindanus snake venom acetylcholinesterase. J Venom Anim Toxins incl Trop Dis. 2012;18(2):236-43. http://dx.doi.org/10.1590/S1678-91992012000200014.

16. Frobert $\mathrm{Y}$, Creminon $\mathrm{C}$, Cousin $\mathrm{X}$, Remy $\mathrm{MH}$, Chatel JM, Bon S, et al. Acetylcholinesterases from Elapidae snake venoms: biochemical, immunological and enzymatic characterization. Biochim Biophys Acta. 1997 May 23;1339(2):253-67.
17. Bawaskar HS, Bawaskar PH. Envenoming by the common krait (Bungarus caeruleus) and Asian cobra (Naja naja): clinical manifestations and their management in a rural setting. Wilderness Environ Med. 2004;15(4):257-66.

18. Cousin X, Creminon C, Grassi J, Meflah K, Cornu G, Saliou B, et al. Acetylcholinesterase from Bungarus venom: a monomeric species. FEBS Lett. 1996 Jun 3;387(2-3):196-200.

19. Chippaux JP. Snake-bites: appraisal of the global situation. Bull World Health Organ. 1998;76(5):515-24.

20. McNamee D. Tackling venomous snake bites worldwide. Lancet. 2001 May 26;357(9269):1680.

21. Warrell DA. The clinical management of snake bites in Southeast Asian region. Southeast Asian J Trop Med Public Health. 1999;30(Suppl 1):1-67.

22. Sharma SK, Koirala S, Dahal G. Krait bite requiring high dose antivenom: a case report. Southeast Asian J Trop Med Public Health. 2002 Mar;33(1):170-1.

23. Hartinger CG, Dyson PJ. Bioorganometallic chemistry--from teaching paradigms to medicinal applications. Chem Soc Rev. 2009 Feb;38(2):391401.

24. Silva T, Reis J, Teixeira J, Borges F. Alzheimer's disease, enzyme targets and drug discovery struggles: from natural products to drug prototypes. Ageing Res Rev. 2014 May;15:116-45.

25. Dey A, Bhattacharya R, Mukherjee A, Pandey DK. Natural products against Alzheimer's disease: Pharmaco-therapeutics and biotechnological interventions. Biotechnol Adv. 2017 Mar-Apr;35(2):178-216.

26. David B, Wolfender JL, Dias DA. The pharmaceutical industry and natural products: Historical status and new trends. Phytochem Rev. 2015;14(2):299-315.

27. Asha H. A review: natural compounds as anti-Alzheimer's disease agents. Curr Nutr Food Sci. 2017 Jul;13(4):247-54.

28. Andrade S, Ramalho MJ, Loureiro JA, Pereira MC. Interaction of natural compounds with biomembrane models: A biophysical approach for the Alzheimer's disease therapy. Colloids Surf B Biointerfaces. 2019 Aug 1;180:83-92.

29. Butler MS, Robertson AA, Cooper MA. Natural product and natural product derived drugs in clinical trials. Nat Prod Rep. 2014 Nov;31(11):1612-61.

30. Rajitha B, Naveen KV, Someshwar P, Venu MJ, Narsimha RP, Thirupathi RY. Dipyridine copper chloride catalyzed coumarin synthesis via pechmann condensation under conventional heating and microwave irradiation. Arkivoc. 2006 Jun:23-7.

31. O'Kennedy R, Thornes RD. Coumarins: biology, applications and mode of action. Chichester: Wiley. 1997.

32. Zahradník M. The production and application of fluorescent brightening agents. Chichester, Sussex, New York, Wiley. 1983.

33. Al-Masoudi NA, Abdullah BH, Essa AH, Loddo R, LaColla P. Platinum and palladium-triazole complexes as highly potential antitumor agents. Arch Pharm (Weinheim). 2010 Apr;343(4):222-7.

34. Qurrat-ul-Ain, Rasheed S, Mahroof-Tahir M, Ashiq U, Jamal RA. Antiurease, Antiphosphodiesterase and Antiglycation Studies of Pd(II) Complexes with Monodentate Hydrazides. J Chem Soc Pak. 2016 Nov;38(5):864-81.

35. Bajgar J. Organophosphates/nerve agent poisoning: mechanism of action, diagnosis, prophylaxis, and treatment. Adv Clin Chem. 2004;38:151-216.

36. Marrs TC. Organophosphate poisoning. Pharmacol Ther. 1993;58(1):51-66.

37. Khan SZ, Rehman Z, Burler IS, Gariepy FB New ternary palladium(II) complexes: Synthesis, Characterization, in vitro anticancer and antioxidant activities. Inorg. Chem. Commun. 2019, 105:140-146.

38. Bradford DS, Thompson RC. Fractures and dislocations of the spine. Indications for surgical intervention. Minn Med. 1976 Oct;59(10):711-20.

39. Ahmed M, Batista J, Rocha T, Mazzanti CM, Hassan W, Morsch VM. Comparative study of the inhibitory effect of antidepressants on cholinesterase activity in Bungarus sindanus (krait) venom, human serum and rat striatum. J Enzyme Inhib Med Chem. 2008 Dec;23(6):912-7.

40. Rocha JB, Emanuelli T, Pereira ME. Effects of early undernutrition on kinetic parameters of brain acetylcholinesterase from adult rats. Acta Neurobiol Exp (Wars). 1993;53(3):431-7.

41. Lineweaver H, Burk D. The Determination of Enzyme Dissociation Constants. J Am Chem Soc. 1934(56):658-66. 
42. Hofstee $\mathrm{BH}$. On the evaluation of the constants $\mathrm{Vm}$ and $\mathrm{K}_{\mathrm{m}}$ in enzyme reactions. Science. 1952 Sep 26;116(3013):329-31.

43. Dowd JE, Riggs DS. A comparison of estimates of michaelis-menten kinetic constants from various linear transformations. J Biol Chem. 1965 Feb;240:863-9.

44. Dixon M, Webb EC. Enzymes. London: Longmans. 1964.

45. Lahiri DK, Rogers JT, Greig NH, Sambamurti K. Rationale for the development of cholinesterase inhibitors as anti-Alzheimer agents. Curr Pharm Des. 2004;10(25):3111-9.

46. O'Brien JT, Ballard CG. Drugs for Alzheimer's disease. BMJ. 2001;323(7305):123-4.
47. Ahmad M, Weber AD, Zanon G, Tavares LdC, Ilha V, Dalcol II, et al. Inhibitory and enzyme-kinetic Investigation of chelerythrine and lupeol Isolated from Zanthoxylum rhoifolium against krait snake venom acetylcholinesterase. J Braz Chem. 2014;25(1).

48. Marone S, Rozas I, Weaver DF. Theoretical structural analyses of tricyclic neuroactive drugs: quantum pharmacologic descriptors for clustering anticonvulsant, antidepressant, and antipsychotic activities. J Mol Struct. 1999 Jul 1;467(1):25-30.

49. Harel M, Schalk I, Ehret-Sabatier L, Bouet F, Goeldner M, Hirth C, et al. Quaternary ligand binding to aromatic residues in the active-site gorge of acetylcholinesterase. Proc Natl Acad Sci U S A. 1993 Oct 1;90(19):9031-5. 